\title{
Pengendalian Kualitas Kertas Dengan Menggunakan Statistical Process Control di Paper Machine 3
}

\author{
Vera Devani ${ }^{1}$, Fitri Wahyuni ${ }^{2}$
}

\begin{abstract}
Purpose of this research is to determine types and causes of defects commonly found in Paper Machine 3 by using statistical process control (SPC) method. Statistical process control (SPC) is a technique for solving problems and is used to monitor, control, analyze, manage and improve products and processes using statistical methods. Based on Pareto Diagrams, wavy defect is found as the most frequent defect, which is $81.7 \%$. Human factor, meanwhile, is found as the main cause of defect, primarily due to lack of understanding on machinery and lack of training both leading to errors in data input.
\end{abstract}

Keywords. defect, statistical process control, quality control

Abstrak. Penelitian ini dilakukan untuk menganalisa kecacatan produk kertas serta menganalisa faktor-faktor yang menyebabkan kecacatan dengan menggunakan statistical process control. Statistik process control merupakan metode pengambilan keputusan untuk memonitoring, mengendalikan, menganalisa, mengelola serta memperbaiki produk dan proses dengan menggunakan metoda statistik. Berdasarkan diagram Pareto, kecacatan produk yang banyak terjadi terdapat pada kecacatan wavy dengan persentase $81,7 \%$. Faktor penyebab utama kecacatan adalah faktor manusia, karena operator yang baru memahami mesin dan kurangnya pelatihan sehingga terjadi kesalahan dalam pengimputan data dan menyebabkan terjadi kecacatan pada produk.

Kata Kunci. kecacatan, pengendalian kualitas, statistical process control

\section{Pendahuluan}

PT. IK bergerak di bidang manufaktur yang memproduksi pulp dan kertas. Sistem produksi yang dilakukan adalah make to order. Berdasarkan pengamatan yang dilakukan, kecacatan yang sering terjadi pada mesin yang termasuk ke dalam klasifikasi grade dan kecacatan A - Sortir yang terdiri dari beberapa cacat, diantaranya wavy $(\mathrm{G} 2$ atau gelombang), rewinder wringkle (L1 atau lipatan mati rewinder), less diameter (D3 atau diameter roll kurang), dan dented rolljoint (R1 atau rusak karena bantingan). Dari pengamatan yang dilakukan pada bulan Januari 2013 pada produk kertas A - Sortir dengan jumlah produksi

\footnotetext{
${ }^{1}$ Vera Devani, Jurusan Teknik Industri, UIN Sultan Syarif Kasim Riau, Jl. H.R. Soebrantas No. 155, Simpang Baru Panam, Pekanbaru (email: veradevani@gmail.com)

${ }^{2}$ Fitri Wahyuni, Jurusan Teknik Industri, UIN Sultan Syarif Kasim Riau, Jl. H.R. Soebrantas No. 155, Simpang Baru Panam, Pekanbaru
}

Diajukan: 02-02-2016 Disetujui: 30-11-2016
26.746.441 ton dengan jumlah kecacatan 961.985 ton berarti dengan rata-rata produksi perhari 891.548 ton terdapat rata-rata kecacatan per hari adalah 32.066 ton. Berdasarkan masalah yang dihadapi perusahaan, yaitu banyaknya kecacatan A-Sortir di Paper Machine 3 maka perlu dilakukan upaya mengendalikan kualitas produk kertas untuk mencari penyebab terjadi kecacatan serta mencari solusi perbaikannya.

Ayuni, dkk. (2012) menyatakan bahwa pengendalian merupakan ketentuan apa yang harus dilaksanakan, menilai dan mengoreksi pelaksanaannya bila perlu dengan maksud supaya pelaksanaan pekerjaan sesuai dengan rencana semula. Definisi lain oleh Sultana dkk. (2009), statistical process control (SPC) digunakan untuk mengendalikan proses produksi secara berkesinambungan dan mengidentifikasi kerusakan yang terjadi ketika proses produksi berlangsung. SPC juga digunakan untuk mengumpulkan dan menganalisis data hasil pemeriksaan terhadap sampel dalam kegiatan pengawasan kualitas produk (Arifianti, 2013). Selain itu SPC juga digunakan untuk mengukur kualitas sekarang dari produk atau jasa dan mendeteksi apakah proses barang atau jasa 
mengalami perubahan yang akan mempengaruhi kualitas (Heizer dan Render, 2005 dikutip oleh Kartika, 2013)

\section{Pengendalian Kualitas}

Kualitas barang atau jasa dapat berkenaan dengan keandalan, ketahanan, waktu yang tepat, penampilannya, integritasnya, kemurniannya, individualitasnya, atau kombinasi dari berbagai faktor tersebut. Uraian di atas menunjukkan bahwa pengertian kualitas dapat berbeda-beda pada setiap orang pada waktu khusus dimana kemampuannya (availability), kinerja (performance), keandalan (reliability), dan kemudahan pemeliharaan (maintainability) dan karakteristiknya dapat diukur. Ditinjau dari sudut pandang produsen, kualitas dapat diartikan sebagai kesesuaian dengan spesifikasinya. Suatu produk akan dinyatakan berkualitas oleh produsen, apabila produk tersebut telah sesuai dengan spesifikasinya.

Menurut Deming, kualitas adalah apapun yang menjadi kebutuhan dan keinginan konsumen, sedangkan menurut Crosby mempersepsikan, kualitas sebagai nihil cacat, kesempurnaan dan kesesuaian terhadap persyaratan (Yamit, 2005).

Menurut Nasution (2005) ada beberapa persamaan dalam definisi kualitas, yaitu dalam elemen-elemen sebagai berikut: (1) kualitas mencakup usaha memenuhi atau melebihi harapan pelanggan, (2) kualitas mencakup produk, jasa manusia, proses, dan lingkungan, dan (3) kualitas merupakan kondisi yang selalu berubah (misalnya apa yang dianggap merupakan kualitas saat ini mungkin dianggap kurang berkualitas pada masa mendatang).

Faktor yang mempengaruhi pengendalian kualitas yang dilakukan perusahaan (Douglas C. Montgomery, 2001 dikutip oleh Bakhtiar, dkk., 2013):

1. Kemampuan proses. Batas-batas yang ingin dicapai haruslah disesuaikan dengan kemampuan proses yang ada. Tidak ada gunanya mengendalikan suatu proses dalam batas-batas yang melebihi kemampuan atau kesanggupan proses yang ada.

2. Spesifikasi yang berlaku, hasil produksi yang ingin dicapai harus dapat berlaku, bila ditinjau dari segi kemampuan proses dan keinginan atau kebutuhan konsumen yang ingin dicapai dari hasi produksi tersebut. Dapat dipastikan dahulu apakah spesifikasi tersebut dapa tberlaku sebelum pengendalian kualitas pada proses dapat dimulai.

3. Tingkat ketidaksesuaian yang dapat diterima. Tujuan dilakukan pengendalian suatu proses adalah dapat mengurangi produk yang berada di bawah standar seminimal mungkin. Tingkat pengendalian yang diberlakukan tergantung pada banyaknya produk yang berada di bawah standar.

4. Biaya kualitas, sangat mempengaruhi tingkat pengendalian dalam menghasilkan produk dimana biaya mempunyai hubungan yang positif dengan terciptanya produk yang berkualitas.

\section{Statistical Process Control}

Pengendalian kualitas statistik dilakukan dengan menggunakan alat bantu statistik yang terdapat pada SPC (statistical process control) dan SQC (statistical quality control) merupakan teknik penyelesaian masalah yang digunakan untuk memonitor, mengendalikan, menganalisis, mengelola dan memperbaiki produk dan proses menggunakan metode statistik. Pengendalian kualitas statistik (statistical quality control atau SQC) sering disebut sebagai pengendalian proses statistik (statistical process control atau SPC).

Menurut Dorothea (2003) dikutip oleh Bakhtiar, dkk, (2013), pengendalian kualitas statistic adalah teknik yang digunakan untuk mengendalikan dan mengelola proses baik manufaktur maupun jasa melalui menggunakan metode statistik. Pengendalian kualitas statistik merupakan teknik penyelesaian masalah yang digunakan untuk memonitor, mengendalikan, menganalisis, mengelola dan memperbaiki produk dan proses menggunakan metode-metode statistik.

Pengendalian kualitas secara statistik dengan menggunakan statistical process control (SPC) mempunyai tujuh (7) alat statistik utama yang dapat digunakan sebagai alat bantu untuk mengendalikan kualitas sebagaimana disebutkan juga oleh Heizer dan Render (2005) dikutip oleh Kartika (2013), yaitu check sheet, histogram, control chart, diagram Pareto, diagram sebab akibat, Scatter diagram, dan diagram proses.

Piranti untuk statistical process control (SPC) adalah sebagai berikut:

1. Lembar Pemeriksaan (check sheet), yaitu alat pengumpul dan penganalisis data yang disajikan dalam bentuk tabel yang berisi data 
jumlah barang yang diproduksi dan jenis ketidaksesuaian beserta dengan jumlah yang dihasilkannya. Tujuan digunakannya Check Sheet ini adalah untuk mempermudah proses pengumpulan data dan analisis, serta untuk mengetahui area permasalahan berdasarkan frekuensi dari jenis atau penyebab dan mengambil keputusan untuk melakukan perbaikan atau tidak.

2. Diagram pencar (Scatter diagram), disebut juga dengan peta korelasi adalah grafik yang menampilkan kekuatan hubungan antara dua variabel. Dua variabel yang ditunjukkan dalam diagram pencar dapat berupa karakteristik kuat dan faktor yang mempengaruhinya.

3. Diagram sebab akibat (cause and effect diagram), disebut juga diagram tulang ikan (fishbone chart). Diagram ini memperlihatkan faktor-faktor utama yang berpengaruh pada kualitas dan mempunyai akibat pada masalah yang kita pelajari.

4. Diagram Pareto (Pareto diagram) adalah grafik balok dan grafik baris yang menggambarkan perbandingan masing-masing jenis data terhadap keseluruhan. Fungsi diagram Pareto adalah untuk mengidentifikasi masalah utama untuk peningkatan kualitas dari yang paling besar ke yang paling kecil. Dalam diagram pareto, berlaku aturan $80 / 20$, yang artinya $20 \%$ jenis kecacatan dapat menyebabkan $80 \%$ kegagalan proses (Yuri, 2013).

5. Diagram alir proses (process flow chart), yang secara grafis menunjukkan sebuah proses atau sistem dengan menggunakan kotak dan garis yang saling berhubungan. Diagram sederhana ini merupakan alat yang sangat baik untuk memahami proses atau menjelaskan langkahlangkah sebuah proses.

6. Histogram, merupakan alat bantu untuk menentukan variasi dalam proses, yang berbentuk diagram batang menunjukkan tabulasi dari data yang diatur berdasarkan ukurannya.

7. Peta kendali (control chart), yaitu alat yang secara grafis digunakan untuk memonitor dan mengevaluasi aktivitas atau proses berada dalam pengendalian kualitas secara statistika, sehingga dapat memecahkan masalah dan menghasilkan perbaikan kualitas. Peta kendali menunjukkan adanya perubahan data dari waktu ke waktu, tetapi tidak menunjukkan penyebab penyimpangan meskipun penyimpanan itu akan terlihat pada peta kendali. Beberapa jenis peta kendali atribut, yaitu:

- Peta kendali $p$, yaitu peta kendali untuk bagian yang ditolak karena tidak sesuai terhadap spesifikasi.

- Peta kendali $n p$, yaitu peta kendali untuk banyaknya butir yang tidak sesuai.

- Peta kendali $c$, yaitu peta kendali untuk banyaknya ketidaksesuaian

- Peta kendali $u$, yaitu peta kendali untuk banyaknya ketidaksesuaian per satuan

\section{Metodologi}

Data yang dibutuhkan dalam penelitian ini adalah jumlah produksi bulan Januari dan bulan Februari 2013 dan jenis kecacatan yang termasuk dalam kategori kelas A-sortir, terdiri dari wavy ( $\mathrm{G} 2$ atau gelombang), rewinder wrinkle (L1 atau lipatan mati ), less diameter (D3 atau diameter roll kurang), dented roll/joint (R1 atau rusak karena bantingan). Metode yang digunakan pada penelitian ini adalah metode statistical process control. Piranti yang digunakan pada pengolahan data adalah histogram, diagram Pareto, diagram pencar, dan peta kendali p. Untuk menganalisa penyebab terjadinya kecacatan digunakan diagram fishbone.

\section{HASIL DAN PEMBAHASAN}

PT. IK berusaha mempertahankan posisinya sebagai produsen pulp dan kertas dengan biaya rendah serta pelaku utama di pasar Indonesia dan Asia yang tumbuh pesat, dengan mengandalkan keuntungan pada sumber bahan baku, efisiensi produksi, serta jaringan distribusi yang luas.

\section{Histogram kecacatan wavy}

Dari data hasil pengecekan kualitas kertas, maka histogram kecacatan wavy (G2) dapat dilihat pada Gambar 1. Gambar 1 menunjukkan bahwa selama 55 hari pengamatan terlihat bahwa kecacatan wavy sering terjadi pada setiap proses produksi dengan jumlah berkisar 4 sampai dengan 97 cacat. Dari 55 hari pengamatan yang tidak terjadi kecacatan wavy hanya 2 hari. Total kecacatan wavy selama pengamatan adalah 1.348 cacat. 


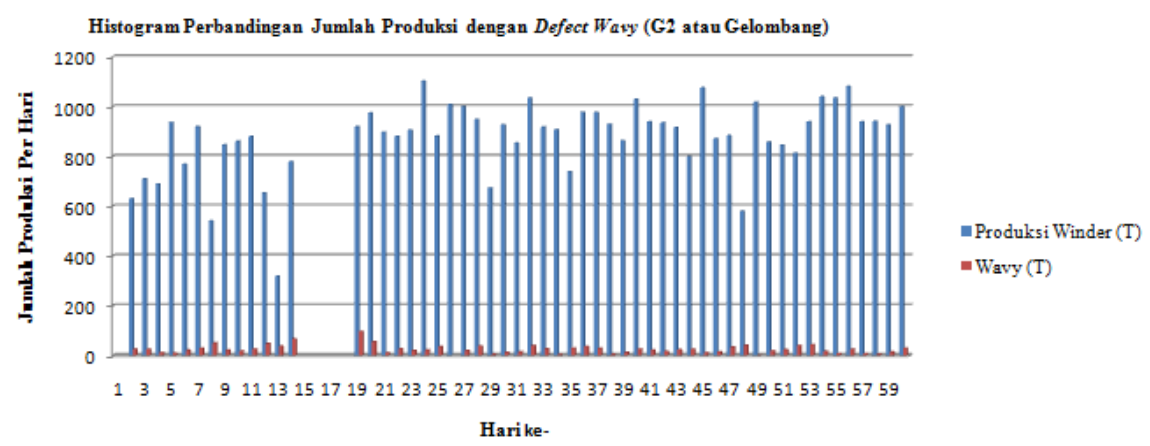

Gambar 1. Histogram perbandingan jumlah produksi dengan kecacatan wavy (G2)

Histogram Perbandingan Jumlah Produksi dengan Defect Rewinder Wrinkle (L1 atau Lipatan Mati pada Rewinder

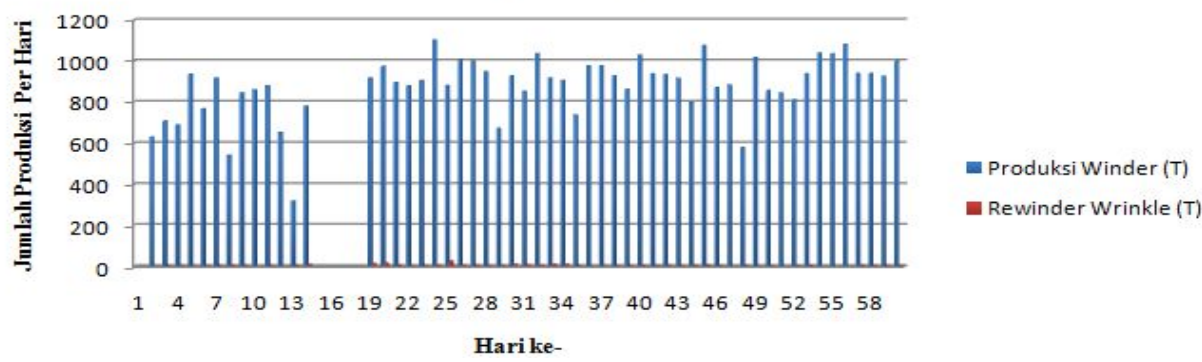

Gambar 2. Histogram perbandingan jumlah produksi dengan kecacatan rewinder wrinkle (L1)

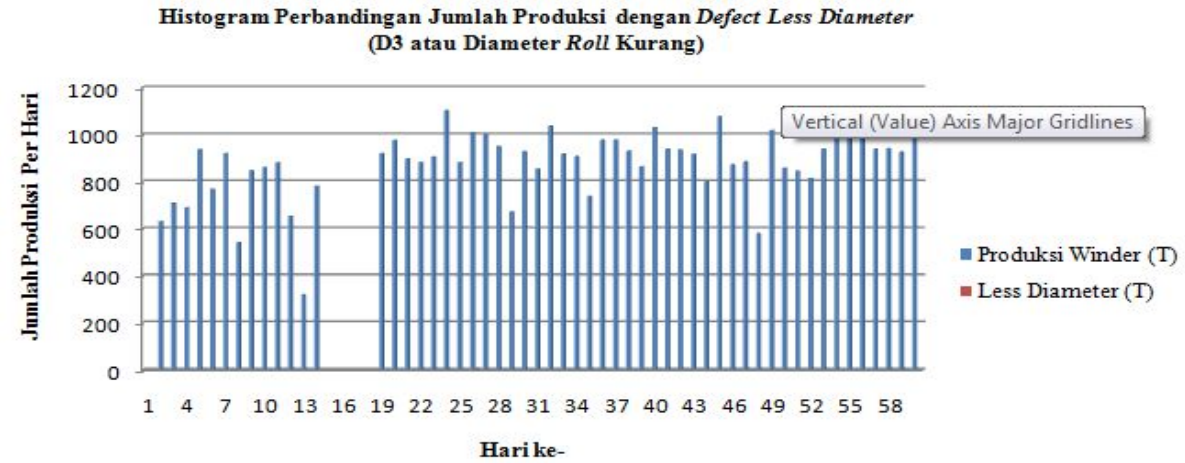

Gambar 3. Histogram perbandingan jumlah produksi dengan kecacatan less diameter (D3)

Histogram Perbandingan Jumlah Produksi dengan Defect Dented Roll Joint (R1 atau Rusak Karena Bantingan)

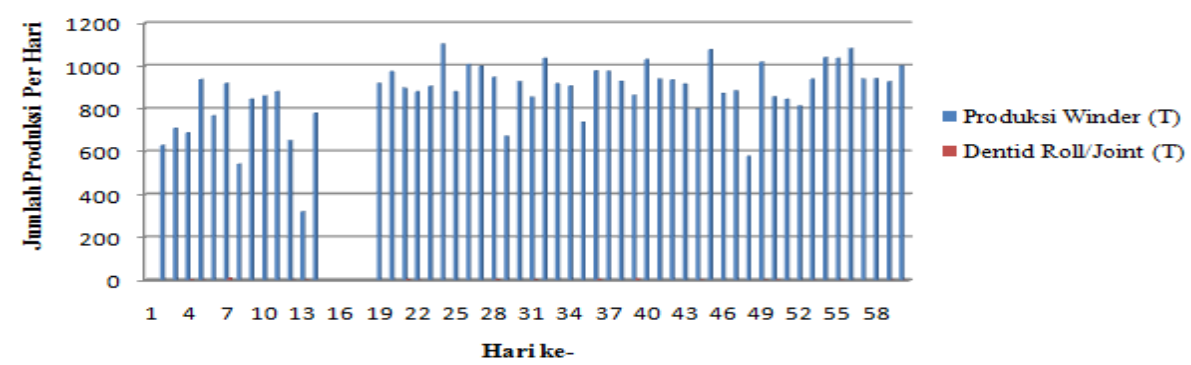

Gambar 4. Histogram perbandingan jumlah produksi dengan kecacatan dented roll/joint (R1) 
Tabel 1. Persentase setiap jenis kecacatan pada klasifikasi grade \& kecacatan A-sortir

\begin{tabular}{clrrr}
\hline No. & Jenis kecacatan & Jumlah & Persentase & $\begin{array}{c}\text { \% } \\
\text { Kumulatif }\end{array}$ \\
\hline 1 & Wavy (gelombang) = G2 & 1.348 & 0,817 & $81,7 \%$ \\
2 & Rewinder wrinkle (lipatan mati rewinder) = L1 & 242 & 0,147 & $96,4 \%$ \\
3 & Dented roll/ joint (rusak karena bantingan) = R1 & 55 & 0,033 & $99,7 \%$ \\
4 & Less diameter (diameter roll kurang) = D3 & 5 & 0,003 & $100 \%$ \\
& Total & $\mathbf{1 . 6 5 0}$ & & \\
\hline
\end{tabular}

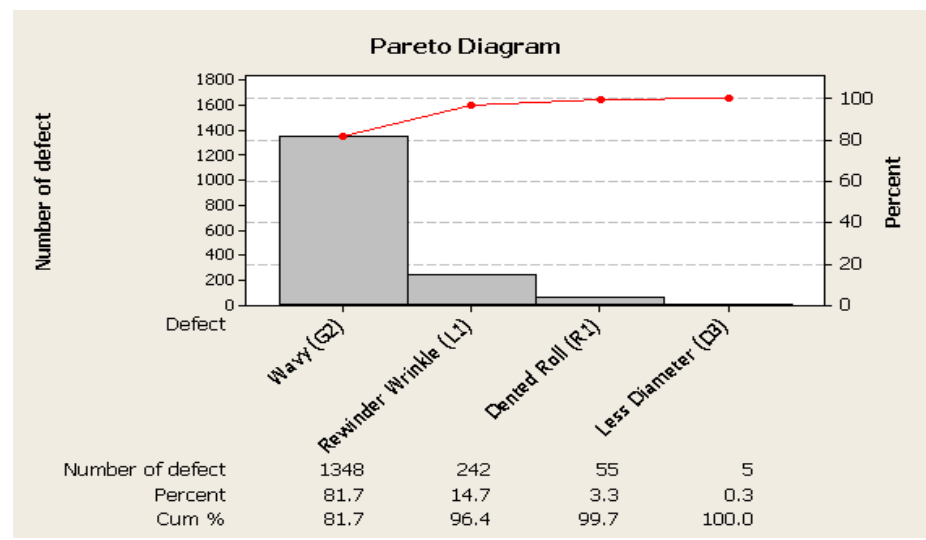

Gambar 5. Diagram Pareto pada klasifikasi grade dan kecacatan A-sortir

\section{Histogram Kecacatan Rewinder Wrinkle}

Dari data hasil pengecekan kualitas kertas, maka histogram kecacatan rewinder wrinkle (L1) dapat dilihat pada Gambar 2. Gambar 2 menunjukkan selama 55 hari pengamatan terlihat bahwa kecacatan rewinder wrinkle jarang terjadi pada setiap proses produksi. Total kecacatan rewinder wrinkle selama pengamatan adalah 242 cacat.

\section{Histogram Kecacatan Less Diameter}

Dari data hasil pengecekan kualitas kertas, maka histogram kecacatan less diameter (D3) dapat dilihat pada Gambar 3. Gambar 3 menunjukkan selama 55 hari pengamatan terlihat bahwa less diameter sangat jarang terjadi pada setiap proses produksi. Total less diameter selama pengamatan adalah 5 cacat.

\section{Histogram Kecacatan Dented Roll}

Dari data hasil pengecekan kualitas pada kertas, maka histogram kecacatan dented roll atau joint (R1) dapat dilihat pada Gambar 4. Gambar 4 menunjukkan selama 55 hari pengamatan terlihat bahwa kecacatan dented roll atau joint sangat jarang terjadi pada setiap proses produksi. Total kecacatan dented roll atau joint selama pengamatan adalah 55 cacat.

\section{Diagram Pareto (Pareto Diagram)}

Persentase setiap jenis kecacatan pada klasifikasi grade \& kecacatan A-sortir di paper machine pada kurun waktu bulan JanuariFebruari 2013 ditampilkan pada Tabel 1. Adapun diagram Pareto pada klasifikasi grade \& kecacatan A-sortir di paper machine tersebut ditunjukkan pada Gambar 5, yang memperlihatkan kecatatan yang terjadi pada bulan Januari-Februari 2013 didominasi oleh kecacatan wavy (G2) sebesar 81,7\%. Oleh karena itu, perbaikan diprioritaskan pada jenis kecacatan wavy (G2).

\section{Diagram Pencar (Scatter Diagram)}

Diagram pencar (Scatter diagram) untuk jenis kecacatan wavy (G2), pada Gambar 6, yang 
memperlihatkan bahwa terdapat korelasi negatif antara jumlah produksi dan jumlah kecacatan wavy.

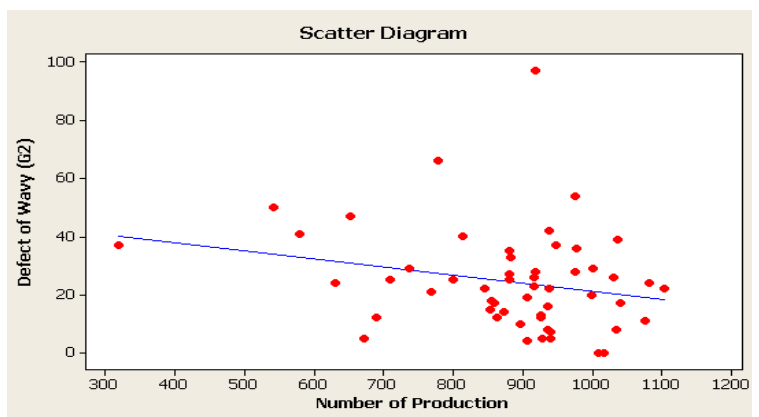

Gambar 6. Diagram pencar untuk kecacatan wavy (G2)

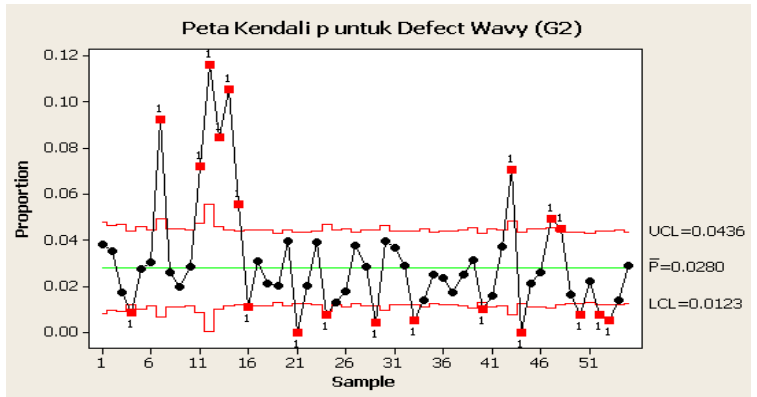

Tests performed with unequal sample sizes

Gambar 7. Peta kendali p untuk kecacatan wavy (G2)

\section{Peta Kendali $p$}

Peta kendali $p$ digunakan untuk mengukur proporsi ketidaksesuaian (penyimpangan atau sering disebut cacat) dari item-item dalam kelompok yang sedang diinspeksi. Peta kendali $p$ untuk kecacatan wavy (G2) yang terjadi pada bulan Januari-Februari 2013, diperlihatkan pada Gambar 7 dan Gambar 8 .

Gambar 7 memperlihatkan bahwa terdapat 20 hari dari 55 hari pengamatan berada di luar batas kendali, sehingga bisa dikatakan produk tidak terkendali. Karena masih terdapat kecacatan wavy yang berada di luar batas kendali maka dilakukan revisi dengan cara mengeluarkan nilai yang berada di luar kendali dan melakukan perhitungan ulang.

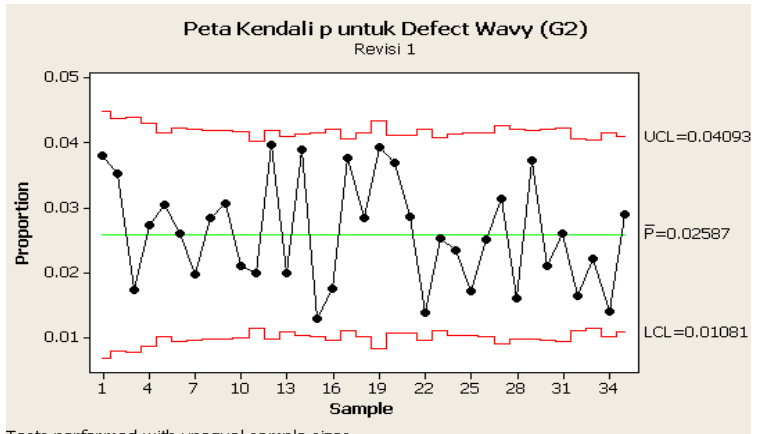

Gambar 8. Peta kendali p untuk kecacatan wavy (G2) revisi 1

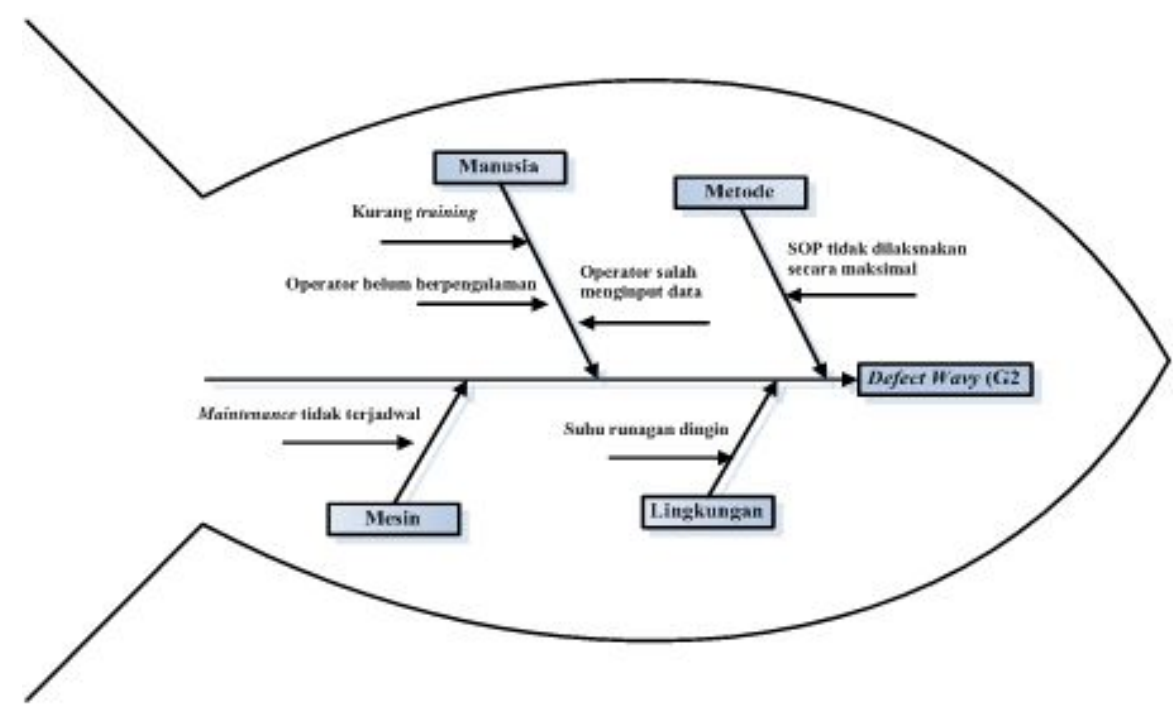

Gambar 9. Diagram tulang ikan untuk kecacatan wavy (G2) 
Gambar 8 merupakan revisi pertama peta kendali $p$ untuk kecacatan wavy (G2). Gambar 8 memperlihatkan bahwa semua kecacatan wavy (G2) berada dalam batas kendali. Dapat disimpulkan bahwa kecacatan wavy (G2) berada pada batas kendali yang telah ditetapkan.

\section{Diagram Tulang Ikan}

Setelah diketahui jenis cacat yang dominan terjadi dari Pareto Diagram, perlu dilakukan langkah-langkah perbaikan untuk mengurangi kecacatan tersebut. Diagram Tulang Ikan merupakan alat yang digunakan untuk mengetahui faktor-faktor utama penyebab cacat. Penyebab utama terjadinya kecacatan wavy (G2) dapat dilihat pada Gambar 9.

Terjadinya kecacatan wavy disebabkan oleh 4 faktor, yaitu terkait dengan mesin, manusia, metode dan lingkungan. Dari faktor mesin, penyebab terjadinya kecacatan wavy adalah tidak dilakukannya perawatan (maintenance) secara terjadwal. Perawatan dilakukan jika ditemui terjadinya kerusakan mesin.

Dari faktor sumber daya manusia, terjadinya kecacatan wavy disebabkan oleh adanya operator yang belum berpengalaman, kurang mendapatkan pelatihan, atau terjadinya kesalahan operator dalam memasukkan data. Turn over karyawan yang tinggi menyebabkan perlunya pelatihan dilakukan secara rutin bagi operator.

Dari faktor metode, terjadinya kecacatan wavy dikarenakan prosedur operasional baku tidak dijalankan dengan baik dan benar. Adapun dari faktor lingkungan, kecacatan wavy terjadi karena suhu ruangan yang dingin dan menyebabkan ruangan kerja yang lembab.

\section{SIMPULAN}

Berdasarkan Diagram Pareto, diketahui bahwa cacat kertas paling dominan terjadi adalah jenis kecacatan wavy (G2). Faktor utama penyebab kecacatan wavy adalah maintenance dilakukan tidak terjadwal dengan baik, operator baru yang kurang memahami mesin, operator salah menginputkan data, kurangnya training dari perusahaan, tidak dilaksanakan Standard Operasional Procedure (SOP) secara maksimal, dan suhu ruangan dingin sehingga ruangan kerja menjadi lembab.

\section{DAFTAR PUSTAKA}

Arifianti, R. 2013. "Analisis kualitas produk sepatu Tomkins". Jurnal Dinamika Manajemen. Vol. 4 (1), pp: 46-58.

Ayuni, D.; Siswandaru, K.; Nupikso, G. 2012. "Analisis penerapan statistical quality control pada beban usaha PT. PLN". Jurnal Organisasi dan Manajemen. Vol. 8 (1), pp: 22-31.

Bakhtiar, S.; Tahir, S.; dan Hasni, R.A. 2013. "Analisa pengendalian kualitas dengan menggunakan metode statistical quality control (SQC)". Malikussaleh Industrial Engineering Journal. Vol 2 (1), pp.: 29-36.

Heizer, J.; Render, B. 2005. Manajemen Operasi. Edisi 7. Jakarta: Salemba Empat.

Kartika, H. 2013. "Analisis pengendalian kualitas produk CPE film dengan metode statistical process control pada PT. MSI". Jurnal Ilmiah Teknik Industri. Vol. 1 (1), pp.: 50-58.

Nasution, M.N. 2005. Manajemen Mutu Terpadu (Total Quality Manajemen). Jakarta: Ghalia Indonesia.

Yamit, Z. 2005. Manajemen Kualitas Produk dan Jasa, Yogyakarta: Ekonisia.

Yuri, M.Z.; Rahmat, N. 2013. TQM Manajemen Kualitas Total dalam Perspektif Teknik Industri. Jakarta: PT. Indeks. 